\title{
A framework for developing excellence as a clinical educator
}

\author{
E A Hesketh, ${ }^{1} G$ Bagnall, ${ }^{2} E$ G Buckley, ${ }^{3} M$ Friedman, ${ }^{1}$ E Goodall, ${ }^{4} R$ M Harden, ${ }^{1} \mathcal{F} M$ Laidlaw, ${ }^{1}$ \\ L Leighton-Beck, ${ }^{5}$ P McKinlay, ${ }^{6}$ R Newton ${ }^{7}$ \& $R$ Oughton ${ }^{7}$
}

The current emphasis on providing quality undergraduate and postgraduate medical education has focused attention on the educational responsibilities of all doctors. There is a greater awareness of the need to train doctors as educators and courses have been set up to satisfy this need. Some courses, such as those on how to conduct appraisal, are specific to one task facing a medical educator. Other courses take a broader view and relate educational theory to practice. In this paper we describe an outcome-based approach in which competence in teaching is defined in terms of 12 learning outcomes. The framework provides a holistic approach to the roles of the teacher and supports the professionalism of teaching. Such a framework provides the basis for the development of a curriculum for teaching excellence. It helps to define important competences for different categories of teachers, communicate the areas to be addressed in a course, identify gaps in course provision, evaluate courses, assist in staff planning and allow individuals to assess their personal learning needs. The framework is presented to encourage wider debate.

Keywords Curriculum; education, medical, graduate, methods; education, medical, undergraduate, methods; faculty, *standards; * professional competence; *teaching.

Medical Education 2001;35:555-564

\section{Background}

\section{Recognition of the need for training the trainers}

The importance of providing quality undergraduate and postgraduate medical education has been recognized for a long time, but perhaps never more than at present, with today's climate of increased accountability. Recently, interest in medical education has focused on the teachers/trainers themselves and the quality of the educational experience they offer students and trainees.

In 1991 a report to the Scottish Office ${ }^{1}$ recognized that:

\footnotetext{
${ }^{1}$ Education Development Unit, Scottish Council for Postgraduate Medical and Dental Education, Dundee, UK

${ }^{2}$ West of Scotland Deanery, Glasgow, UK

${ }^{3}$ Scottish Council for Postgraduate Medical and Dental Education, Edinburgh, UK

${ }^{4}$ Royal College of Physicians and Surgeons of Glasgow, Glasgow, UK

${ }^{5}$ Postgraduate Medical Department, Aberdeen, UK

${ }^{6}$ Lister Postgraduate Institute, Edinburgh, UK

${ }^{7}$ Postgraduate Medical Office, Dundee, UK

Correspondence: Mrs E Anne Hesketh, Education Development Unit, Tay Park House, 484 Perth Road, Dundee DD2 1LR, UK
}

...a major factor influencing the quality of training is the competence of the trainer as a teacher. The training needs of trainers should be recognised and met.

The report suggested some aims of a staff development programme specifically for educators and trainers. Other reports by the Standing Committee on Postgraduate Medical and Dental Education (SCOPME) ${ }^{2-4}$ and the British Medical Association (BMA) ${ }^{5}$ focused on similar issues.

Recent General Medical Council (GMC) publications such as The New Doctor, ${ }^{6}$ The Early Years ${ }^{7}$ and now The Doctor as Teacher, ${ }^{8}$ also focus on the doctor as a teacher/trainer. The first two publications specify the educational responsibilities of all involved in the provision of training, be they postgraduate clinical tutor, educational supervisor, or simply other medical staff who work with the trainee. The third draws attention to the professional and personal attributes required of doctors with responsibilities for clinical training/educational supervision.

Other developments in the NHS have also led to an increased emphasis on doctors as educators. The Calman reforms have resulted in the reduction of the length of specialist training. This, combined with the 


\section{Key learning points}

Competence in teaching is described in terms of a framework of 12 learning outcomes.

The framework identifies the teaching tasks undertaken by doctors, how the doctor approaches these tasks and the professional aspects of being a teacher in the medical setting.

The framework can be used to evaluate teaching skills and training provision.

New Deal, has meant that training has become shorter and must become more effective. ${ }^{9,10}$

In higher education too, as a result of recommendations by Dearing ${ }^{11}$ and Garrick, ${ }^{12}$ there is now a move to require all new lecturers in the UK to complete an accredited course in teaching or to have equivalent experience. This is leading the medical profession to think in the long term about appropriate certification and accreditation for doctors involved in teaching/ training at various levels.

There are also sound educational developments which underpin this increasing recognition of the need for training doctors as educators. These include:

- an acceptance of the need for more systematic planning of the learning experience;

- the move away from the 'apprenticeship' model to experiential learning for work-based learning;

- newer approaches to teaching and learning, including the use of new technologies and simulators which require specific skills for effective usage;

- changes in assessment and appraisal techniques, including the use of a range of new performance assessment instruments;

- approaches to standard setting based on the use of reliable and valid instruments;

- recognition of the importance of education strategies to support on-the-job learning.

\section{The increase in course provision}

A key problem is that, for the most part, those engaged in medical training activities have little or no formal training as educators, although courses in medical education have been available for many years. Challis and colleagues, ${ }^{13}$ for example, specifically identified a need for further training and support for those involved in educational supervision. However a significant step forward has been the development of a range of courses aimed at all with an education role - not just the enthusiast.
Many of the courses on offer have been developed in response to the well-documented, immediate needs of the trainer, e.g. courses in appraisal and assessment. Some courses are task-specific, focusing on teaching tasks such as small group teaching. Others emphasize the wider concept of teaching in clinical practice, covering issues such as learner support, sensitization to the needs of individual doctors and the creation of a learning environment. ${ }^{14}$ Some courses address these issues and, for example, incorporate some learning theory as well as specific teaching tasks.

\section{Learning outcomes for the good teacher}

The process of teaching is sometimes distinguished from education or training. Often the three different words are used interchangeably. Many doctors and educators have strong and differing feelings with regard to the use of the terms 'teacher', 'trainer' and 'educator'. We have adopted from this point forward the word 'teacher' to describe the doctor's varying education roles as used in the GMC document The Doctor as a Teacher. ${ }^{8}$ There is, however, enormous diversity in the teaching responsibilities of doctors and the skills required of them. The 12 different roles of the medical teacher have been described. ${ }^{15}$ The doctors' roles and responsibilities will depend on whether or not they have a 'formal' teaching role, e.g. educational supervisor, in addition to their 'informal' teaching role, e.g. consultant working with junior members of the health care team. The responsibilities will also depend on the position the doctor holds for that 'informal' teaching role, e.g. whether they are a senior house officer or consultant. Added to this they will all have diverse personal qualities and characteristics which will influence their approach to teaching and training. Their needs for developing their teaching skills are therefore likely to be quite different. Training provision should match these individual needs.

Learning outcomes for courses on teaching should therefore be clearly stated in order that doctors can make choices appropriate to their needs. ${ }^{14}$ This paper identifies a holistic set of learning outcomes which embraces the full range of teaching competences which contribute to teaching excellence - one that provides a framework for the effective training of doctors as teachers.

\section{Outcome-based education}

Outcome-based education is 'a way of designing, developing, delivering and documenting instruction in terms of its intended goals and outcomes'. ${ }^{16}$ In 
education generally there is increasing interest in outcome-based education with a greater emphasis on the product rather than the process, ${ }^{16}$ and the concept, advantages and applications have been described. ${ }^{17}$ In outcome-based education the learning outcomes are made explicit and the decisions about content, teaching/training method, educational strategies and assessment are related to these outcomes.

Outcomes are a means of identifying and defining which skills and qualities any teacher wants their learners to achieve at the end of training or a course. The terms 'aims', 'goals', 'objectives' and 'outcomes' are often used freely and apparently indiscriminately. Many workers regard the terms as not synonymous. Learning outcomes 'are not fettered by the constraints of behaviourism'. ${ }^{18}$ They offer a framework for looking at competence in an area which goes beyond the cognitive, psychomotor and affective domains. ${ }^{17}$ Outcomeled education is increasingly being used as a means of 'making explicit the criteria against which the success of both the course and the students should be judged'. ${ }^{19}$

In this paper we argue that the outcome-based approach can be usefully adopted in specifying the outcomes expected of courses for doctors as teachers. By using an outcome model one can gain a picture of a professional teacher in the medical setting - the tasks they perform and their associated attributes and qualities. We argue that such an approach assists in identifying the curriculum for training doctors as teachers and can provide a framework for their self-development.

\section{Development of an outcome framework for the doctor as a teacher}

\section{Methods}

Learning outcomes for the effective teacher have been determined through a four-stage process. This work is reported here, together with a framework for presentation of the outcomes with a view to encouraging a wider debate on the topic. The four stages were:

1 examination of the literature;

2 study of the content of local courses for teachers in medicine;

3 preparation of a framework based on the desirable learning outcomes identified above, and

4 review of the framework through discussion with colleagues, followed by further refinement of the framework.

\section{Examination of the literature}

Literature on the topic was identified through the Topics in Medical Education (TIME) database. This is a unique collection of approximately 12000 medical education references available free on the University of Dundee Centre for Medical Education website. It is also available through the Association for the Study of Medical Education (ASME) and the Association for Medical Education in Europe (AMEE) websites.

Papers already cited in this article contributed to the picture of an effective teacher in the clinical setting. Other relevant papers examined included that of Stritter et al. ${ }^{20}$ who identified core non-clinical competences essential for clinicians, many of which relate to teaching. Irby ${ }^{21}$ identified components of knowledge essential to clinical teachers for excellence in teaching.

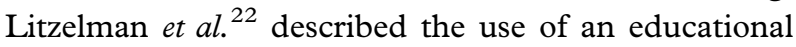
framework within which Stanford Faculty Development programme defined the components of effective clinical teaching. Pinsky et al. ${ }^{23}$ looked at 'distinguished teachers' from clinical departments to identify the principles of teaching excellence. Their study focused on doctors who had been identified as excellent teachers by student/trainee ratings and/or doctors who were participants in 'Teaching Scholars Programs'. In the UK, Sidford ${ }^{24}$ carried out a Delphi exercise to assess the needs of general practice (GP) tutors prior to designing an introductory training package in medical education. Stephens \& Woodcock ${ }^{25}$ identified the concerns about teaching of those attending a New Teacher Workshop, also for GP tutors. Whitehouse ${ }^{9}$ described the content of a course set up to develop the adult education skills of consultants, and Wall \& McAleer ${ }^{26}$ have attempted to define a core curriculum for training consultant teachers.

Literature relating to education in general, as opposed to focusing on medical education, was also examined. Beaty ${ }^{27}$ described common features of programmes for teachers in higher education based on current understanding of good practice. Gosling ${ }^{28}$ identified the range of competences of a good teacher to help departments in higher education institutions improve the way they recruit good teachers.

\section{Study of the content of local courses for teachers in medicine}

The content/curriculum of courses currently offered throughout Scotland were also examined. These included the University of Dundee's Diploma in Medical Education and the various short courses offered by the Royal Colleges, such as 'Educating consultants - how should I train my juniors?', 'The skills of examining the MRCS' and 'Physicians as educators'. In addition relevant courses offered by the four Postgraduate Deaneries were also examined. 


\section{Preparation of a framework based on the desirable learning outcomes identified above}

The three-circle model proposed by Harden et al. ${ }^{29}$ (Figure 1) represents the learning outcome appropriate in the training of a doctor as a 'professional able to undertake the necessary clinical tasks in an appropriate manner'. This model has been adapted and applied to the learning outcomes expected of training programmes designed to produce effective teachers. The resulting framework was based on the information collected in stages 1 and 2 .

The inner segment of the diagram represents the tasks teachers might have to undertake as part of their teaching role. Examples of such tasks range from preparing a lecture through to teaching on a ward round or simply giving feedback. These tasks, however, are only part of the picture. It is recognized that other internalized abilities and personal qualities play a considerable role in distinguishing between an excellent teacher and one who merely fulfils the tasks. The middle and outer segments relate to these other attributes and abilities.

The middle segment covers the approach adopted by the teacher in carrying out the tasks identified in the inner segment. Examples are: having an understanding of their teaching practice, empathizing and showing interest in the learners, and reflecting on teaching practice through best evidence-based medical education. The outer segment relates to the professionalism and self-development of the individual as a teacher,

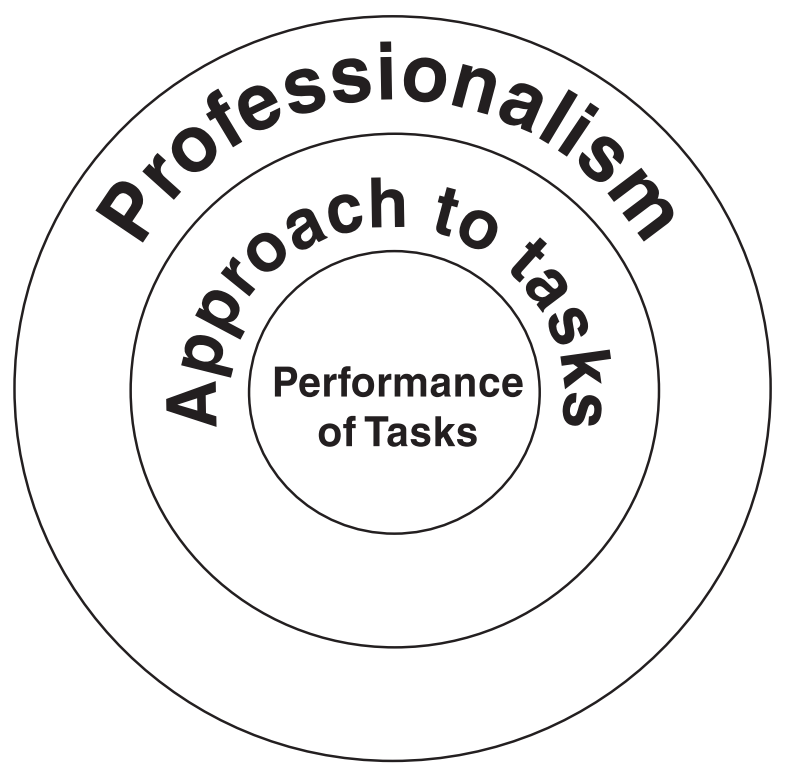

Figure 1 The learning outcomes for the 'effective teacher' based on the three-circle model. e.g. responding to evaluation comments, constructive criticism, etc. from others. Both the middle and outer segments reflect the ability of a doctor to think and act as a teacher. As Harden et al. ${ }^{30}$ describe, 'the competences implicit in the outcomes in the middle and outer circles transcend and act on or work through the competences identified in the outcomes of the inner circle'. Such interaction is a feature of the successful performer.

The learning outcomes for the effective teacher, based on this three-circle model, are translated into 'tree' format and displayed in Table 1. The three segments of the circle model form the first level of the outcome framework. At the second level, 12 key outcomes are defined: seven relating to the inner circle (performance of tasks); three to the middle (approach to tasks), and two to the outer circle (professionalism). Each of the outcomes is made up of a set of clearly defined competences as outlined in the next level. A doctor competent in all the activities shown in the table would be a 'star teacher'.

\section{Discussion with colleagues}

The framework was further defined and refined as a result of discussion between the authors, who include clinicians, professional educators, education technologists and other health care teachers. Also consulted were members of the Supporting Clinical Training in Scotland group which included representation from the Royal Colleges of Scotland as well as the Scottish Council for Postgraduate Medical and Dental Education. As part of the development of the framework it was tested by mapping onto it the outcomes of existing courses for trainers.

\section{The framework}

The revised framework with 12 learning outcomes is shown in Table 1 and is described below. The classification builds on the work by Squires ${ }^{31}$ who analysed the profession of teaching through three questions: What do teachers do? How do they do it? What affects what they do? This approach is complementary to the three-circle model.

\section{The tasks the doctor as teacher is able to do}

Seven core areas of task-oriented competences are described. They can be equated to the 'task-oriented or technical intelligences' described in Harden $e t ~ a l .{ }^{30}$ The learning outcomes in this category are a visible or explicit requirement for the teacher and are relatively easily assessed. 
Outcome 1: competence in teaching large and small groups Doctors as teachers should be competent in giving lectures or presentations. They should also be competent in teaching small groups of people using a range of teaching methods. Where appropriate, being competent in this outcome also means they should be able to organize and run a successful video or telephone conference. In all instances they should be able to ensure participation from all involved in the teaching event. In addition they should be able to use appropriate audiovisual aids using a range of media.

Outcome 2: competence in teaching in a clinical setting Doctors should also be competent in teaching a range of clinical skills in a variety of settings. These skills include teaching clinical, practical and decision-making skills as well as attitudes. Such teaching could be in the ward and associated areas, the clinic, 'on-take', in the community or in a specialized clinical skills unit. In addition, the teachers should be continually aware that they are acting as a role model to trainees through their teaching and non-teaching clinical activities.

\section{Outcome 3: competence in facilitating and managing learning}

This outcome recognizes the importance of facilitator and educational management skills. It is about helping learners to find out how they are doing, pointing them in the right direction and generally helping them to progress, as well as to take more responsibility for their own learning. Such competences will not only assist trainees to develop, but will also ensure poor performance is managed effectively. To undertake this work the doctor, as a teacher, should be competent in carrying out formal appraisal. This will involve a number of competences, including assisting learners to achieve specific learning outcomes; giving feedback; helping learners to self-assess their own skills; drawing up learning contracts, and counselling learners on a range of matters which might be hindering their progress.

\section{Outcome 4: competence in planning learning}

Doctors with a specific educational role, e.g. Clinical Tutor, Postgraduate tutor or Phase Coordinator, also have a responsibility to plan an appropriate training programme for the individual trainee or groups of trainees. This will ensure trainees are offered the right opportunities to progress. In addition to assessing a trainee's educational needs, they should be able to plan and deliver a learning programme using appropriate teaching strategies or offering appropriate learning experiences. The programme should meet the needs of the trainee as well as the expectations associated with the stage of training.

Outcome 5: competence in developing and working with learning resources

Doctors as teachers should be competent at developing and/or using and making best use of appropriate learning support materials. This includes simple handouts, protocols, study guides, multimedia programmes, the Internet and simulators.

Outcome 6: competence in assessing trainees

Effective teachers should be competent in assessing trainee performance. This outcome requires the doctor who is involved in summative or formative assessment to be able to choose and use a range of assessment instruments, including the use of portfolios; to be able to set standards, and to assess the trainees for admission to, or progression through the educational programme.

Outcome 7: competence in evaluating courses and undertaking research in education

Doctors as effective teachers should be competent in evaluation in all educational areas in which they are involved. This includes evaluating courses, teachers and resource materials. The 'star teacher' would also carry out some sound research in education.

\section{How the doctor approaches his/her teaching}

The second group of outcomes covers how teachers approach their teaching practice. These outcomes encompass the 'intellectual, emotional and creative intelligences'. Outcomes in this category are less easy to define and observe but, nevertheless, play an important role in superior job performance.

\section{Outcome 8: with an understanding of the principles} of education (the intellectual intelligences)

This outcome requires doctors as teachers to be familiar with, and have sufficient understanding of, the various approaches to education which can inform their teaching. They should also have an understanding of the educational ideas used in their organization. They should therefore understand basic theories of learning and their practical implications, and be aware of different learning styles. The doctor would be required to understand the principles underpinning a range of teaching and learning techniques, which include problem-based learning, small group learning, outcomebased education, multiprofessional education and giving feedback. Being competent in this outcome 
Table 1 The learning outcomes for the 'effective teacher', based on the three circle model

Level 1
What the doctor as a teacher is able to do 'Doing the right thing'

Technical intelligences

Level 2

\begin{tabular}{|c|c|c|c|c|c|c|}
\hline $\begin{array}{l}1 \text { Teach large } \\
\text { and small } \\
\text { groups }\end{array}$ & $\begin{array}{l}2 \text { Teach in } \\
\text { a clinical } \\
\text { setting }\end{array}$ & $\begin{array}{l}3 \text { Facilitate } \\
\text { and manage } \\
\text { learning }\end{array}$ & $\begin{array}{l}4 \text { Plan } \\
\text { learning }\end{array}$ & $\begin{array}{l}5 \text { Develop } \\
\text { and work } \\
\text { with learning } \\
\text { resources }\end{array}$ & $\begin{array}{l}6 \text { Assess } \\
\text { trainees }\end{array}$ & $\begin{array}{l}7 \text { Evaluate } \\
\text { courses } \\
\text { and undertake } \\
\text { research in } \\
\text { education }\end{array}$ \\
\hline $\begin{array}{l}\text { (1) Prepare a } \\
\text { lecture } \\
\text { (2) Deliver a } \\
\text { lecture } \\
\text { (3) Use } \\
\text { audiovisual } \\
\text { aids, } \\
\text { including } \\
\text { electronic } \\
\text { presentations, } \\
\text { appropriately } \\
\text { (4) Obtain } \\
\text { audience } \\
\text { participation } \\
\text { (5) Choose } \\
\text { appropriate } \\
\text { small group } \\
\text { teaching } \\
\text { methods } \\
\text { (6) Run a small } \\
\text { group } \\
\text { teaching } \\
\text { session } \\
\text { (7) Organize and } \\
\text { run video } \\
\text { and tele- } \\
\text { conferences }\end{array}$ & $\begin{array}{l}\text { (1) Teach } \\
\text { clinical and } \\
\text { practical } \\
\text { skills } \\
\text { (2) Teach } \\
\text { appropriate } \\
\text { attitudes } \\
\text { (3) Teach } \\
\text { decision- } \\
\text { making } \\
\text { skills } \\
\text { (4) Teach in } \\
\text { the ward, } \\
\text { theatre } \\
\text { and } \\
\text { related } \\
\text { areas } \\
\text { (5) Teach in } \\
\text { the clinic } \\
\text { (6) Teach } \\
\text { 'on-take' } \\
\text { (7) Teach in } \\
\text { the } \\
\text { community } \\
\text { (8) Teach in } \\
\text { a clinical } \\
\text { skills unit } \\
\text { (9) Act as a } \\
\text { role model }\end{array}$ & $\begin{array}{l}\text { (1) Carry out } \\
\text { appraisal of } \\
\text { learner and } \\
\text { prepare } \\
\text { report } \\
\text { (2) Assist learners } \\
\text { in achieving } \\
\text { the stated } \\
\text { learning } \\
\text { outcomes } \\
\text { (3) Assist learners } \\
\text { to reflect on } \\
\text { their experiences, } \\
\text { e.g. through } \\
\text { questioning and } \\
\text { feedback } \\
\text { (4) Direct learners } \\
\text { to appropriate } \\
\text { information and } \\
\text { human resources } \\
\text { (5) Assist learners in } \\
\text { self-assessment } \\
\text { skills } \\
\text { (6) Develop learning } \\
\text { contracts } \\
\text { (7) Motivate learners } \\
\text { (8) Counsel learners } \\
\text { on career } \\
\text { (9) Counsel learners } \\
\text { on personal } \\
\text { matters } \\
\text { (10) Counsel learners } \\
\text { on aspects of } \\
\text { learning and } \\
\text { study skills } \\
\text { (11) Assist learners } \\
\text { to organize } \\
\text { their knowledge } \\
\text { and experiences } \\
\text { (12) Assist learners to } \\
\text { make appropriate } \\
\text { use of information } \\
\text { technology }\end{array}$ & $\begin{array}{l}\text { (1) Undertake } \\
\text { an assess- } \\
\text { ment of } \\
\text { learners' } \\
\text { needs } \\
\text { (2) Define the } \\
\text { learning } \\
\text { outcomes } \\
\text { expected } \\
\text { (3) Specify the } \\
\text { content of } \\
\text { the } \\
\text { programme } \\
\text { (4) Design } \\
\text { teaching } \\
\text { strategies } \\
\text { and } \\
\text { learning } \\
\text { experiences } \\
\text { to match } \\
\text { the } \\
\text { outcomes } \\
\text { (5) Prepare a } \\
\text { learning } \\
\text { plan with } \\
\text { timescale } \\
\text { (6) Create an } \\
\text { appropriate } \\
\text { learning } \\
\text { environment } \\
\text { (7) Integrate } \\
\text { different } \\
\text { elements } \\
\text { of the } \\
\text { programme } \\
\text { (8) Implement } \\
\text { planned } \\
\text { course } \\
\end{array}$ & $\begin{array}{l}\text { (1) Design } \\
\text { instructional } \\
\text { text } \\
\text { including } \\
\text { handouts, } \\
\text { handbooks } \\
\text { and } \\
\text { protocols } \\
\text { (2) Make } \\
\text { appropriate } \\
\text { use of study } \\
\text { guides } \\
\text { (3) Design } \\
\text { effective } \\
\text { study } \\
\text { guides } \\
\text { (4) Make } \\
\text { appropriate } \\
\text { use of } \\
\text { videotapes } \\
\text { (5) Contribute } \\
\text { to the } \\
\text { preparation } \\
\text { of multimedia } \\
\text { learning } \\
\text { packages } \\
\text { (6) Use } \\
\text { multimedia } \\
\text { learning } \\
\text { resources } \\
\text { (7) Use the } \\
\text { Internet for } \\
\text { teaching } \\
\text { (8) Plan, and } \\
\text { advise } \\
\text { learners on } \\
\text { the effective } \\
\text { use of } \\
\text { library } \\
\text { facilities } \\
\text { (9) Make } \\
\text { appropriate } \\
\text { use of } \\
\text { clinical } \\
\text { simulators }\end{array}$ & $\begin{array}{l}\text { (1) Choose } \\
\text { appropriate } \\
\text { assessment } \\
\text { instrument } \\
\text { (2) Use } \\
\text { portfolios } \\
\text { (3) Use } \\
\text { written } \\
\text { assessments } \\
\text { (4) Assess } \\
\text { performance } \\
\text { at clinical } \\
\text { examination } \\
\text { (5) Produce } \\
\text { and } \\
\text { interpret } \\
\text { learner } \\
\text { profiles } \\
\text { (6) Set } \\
\text { appropriate } \\
\text { standards } \\
\text { (7) Facilitate } \\
\text { learners' } \\
\text { self- } \\
\text { assessment } \\
\text { (8) Make } \\
\text { appropriate } \\
\text { use of } \\
\text { computers in } \\
\text { assessment } \\
\text { (9) Assess } \\
\text { learners for } \\
\text { admission } \\
\text { to the } \\
\text { educational } \\
\text { programme }\end{array}$ & $\begin{array}{l}\text { (1) Use a range } \\
\text { of tools for } \\
\text { evaluating } \\
\text { courses } \\
\text { (2) Use a range } \\
\text { of tools for } \\
\text { evaluating } \\
\text { teachers } \\
\text { (3) Use a range } \\
\text { tools for } \\
\text { evaluating } \\
\text { resource } \\
\text { materials } \\
\text { (4) Encourage } \\
\text { research in } \\
\text { medical } \\
\text { education } \\
\text { using } \\
\text { sound } \\
\text { educa- } \\
\text { tional } \\
\text { research } \\
\text { techniques }\end{array}$ \\
\hline
\end{tabular}




\begin{tabular}{|c|c|c|}
\hline \multicolumn{2}{|c|}{$\begin{array}{l}\text { How the doctor approaches their teaching } \\
\text { 'Doing the thing right' }\end{array}$} & \multirow{2}{*}{$\begin{array}{c}\text { The doctor as a professional teacher } \\
\text { 'The right person doing it' } \\
\text { Personal } \\
\text { intelligences }\end{array}$} \\
\hline Intellectual intelligences & $\begin{array}{ll}\text { Emotional } & \text { Analytical and } \\
\text { intelligences } & \text { creative intelligences }\end{array}$ & \\
\hline
\end{tabular}

\begin{tabular}{l}
8 With understanding of \\
principles of education \\
\hline (1) Theories of learning \\
(2) Learning styles \\
(3) On-the-job learning \\
(4) Opportunistic learning \\
(5) Problem-based \\
learning/task-based \\
learning \\
(6) Cooperative learning \\
(7) Small group dynamics \\
(8) Principles of \\
instructional design \\
(9) New learning \\
technologies \\
(10) Principles of \\
curriculum planning \\
(11) Outcome-based \\
education \\
(12) Multiprofessional \\
education \\
(13) Distance learning \\
(14) Principles of \\
assessment and \\
feedback \\
(15) Principles of \\
change
\end{tabular}

9 With appropriate attitudes, ethical understanding and legal awareness

10 With appropriate decision-making skills and best evidencebased education

(1) Enthusiasm

(2) Empathy and interest in learners

(3) Respect for student

(4) Openness

(5) Avoids discriminatory actions

(6) Confidentiality

(7) Impartiality

(8) Respect for institutional goals

(9) Values teaching role

(10) Demonstrates intellectual curiosity

(11) Training regulations

(12) Grievance and disciplinary procedures
(1) Use evidence-based medical education as the basis for teaching and learning strategies adopted literature sources on medical education

(3) Is creative and resourceful in their teaching approach

(4) Is able to prioritize workload as teacher
(2) Familiarity with

11 The role of teacher or trainer within the Health Service and the university

12 Personal development with regard to teaching

(1) Understand teaching responsibilities

(2) Maintain an acceptable balance between service commitments, research and teaching

(3) Accept appropriate personal attributes for teachers

(4) Appreciate teacher as researcher

(5) Appreciate doctor as manager of teaching including quality control

(6) Appreciate doctor as a teacher and learner of a multiprofessional team

(7) Encourage a multiprofessional approach to clinical teaching

(8) Appreciate and respect colleagues

(9) Familiarity with teaching recommendations and requirements of the GMC, the specialties and the university
(1) Reflect upon and be aware of own strengths and weaknesses as a teacher

(2) Accept and respond to evaluation comments, constructive criticism, etc. from others

(3) Keep abreast of new teaching and learning techniques 
means the teachers are not only able to carry out the techniques, but that they also understand what they are doing and can justify why they are doing it. Such understanding underpins the 'star teacher's' performance.

Outcome 9: with appropriate attitudes, ethical understanding and legal awareness (emotional intelligences) A doctor who is an effective teacher is also one who takes an appropriate approach and attitude towards teaching and trainees. This includes showing enthusiasm for teaching and learning, as well as developing a positive relationship with trainees. The latter is likely to be achieved through personal qualities, such as having an interest in and respect for the trainee, being open, ethical and impartial. This outcome also requires the doctor to have an awareness of training regulations and grievance issues in order to cope with, for example, a trainee who cheats in an exam or disagrees with an assessment.

Outcome 10: with appropriate decision-making skills and best evidence-based education (analytical

and creative intelligences)

This outcome is primarily about teaching in an educationally sound and creative way. The 'star teacher' uses evidence-based medical education as the basis for their decisions on which teaching and learning strategy to adopt. The outcome also recognizes the creative element in teaching as a source of motivation and inspiration for learners.

\section{The doctor as a professional teacher}

The two categories of outcomes already described focus on what the teacher does and how he/she does it. The outcomes in this third category emphasize the role of teachers within their organization, and their professionalism and personal development as a teachers. The doctor as an effective teacher is aware and has an understanding of his/her own role as a teacher in the overall organization of teaching within the Health Service and university. $\mathrm{He} / \mathrm{she}$ has also accepted responsibility for their own ongoing personal and professional development. For example, with rapid changes in medicine, the technical teaching skills already developed by a teacher may not be appropriate for all developments in the future. It is therefore important that the doctor who has a formal educational role keeps up to date with what is happening in the field of education and reads the right journals. The outcomes in this category are described as the personal intelligences.
Outcome 11: the role of the teacher within the Health Service and the community

This outcome is not only about being aware of the recommendations and requirements for teaching and training, but also about taking them on board: it amounts to being seen to recognize the importance of teaching along with other commitments. It recognizes the doctor as a person who successfully combines being a teacher, a manager of teaching and a researcher in teaching, along with their duties as a physician or surgeon.

\section{Outcome 12: personal development with regard} to teaching

Finally, this outcome is about doctors taking responsibility for their own self-development and becoming lifelong learners with regard to teaching, i.e. including teaching in their professional development through reflection, peer review, feedback, reading or other teaching-related continuing professional development (CPD) activities.

\section{Using the framework}

One of the major strengths of this framework is its comprehensiveness, which means that it can be used for a number of purposes.

\section{Defining competences for different categories of teachers}

The framework can be used to make more explicit and more widely recognized the important competences for different categories of teachers. Doctors acting as educational supervisors, clinical tutors, specialty advisors or doctors at various stages of training will all be involved in different teaching activities. They are also likely to have a wide range of performance abilities especially in the higher order competences. For example the senior house officer and specialist registrar may be encouraged to be effective in questioning and feedback (Table 1, 3 (3)) as well as many other competences but, unlike the educational supervisor/clinical tutor, will not yet be involved in, for example, the assessment process (6 (1-9), 8 (14)) or, as a 'star teacher', be using evidencebased medical education as a basis of all their teaching activities (10 (1)). The overall framework, however, communicates all the outcomes relevant to being an effective and superior teacher.

\section{Communicating the content of courses}

In order that those wishing to go on courses, as well as those commissioning courses, can make informed 
choices, it would be desirable to have a set of standardized course descriptors. ${ }^{14}$ The framework described reflects the wide dimension of effective teaching. Those offering courses can use the framework to identify and communicate which learning outcomes can be achieved by attending their course(s). It is recognized, however, that courses may cover a specific outcome to different depths. For example, with regard to the competence 'having an understanding of the theories of learning', some courses cover the topic of teaching and learning theory in depth, while others only offer an overview of basic principles of how adults learn, whilst focusing mainly on a technical competence. Decisions have to be taken on whether a course should offer breadth across all qualities or be designed to give in-depth training in one area. To address this issue we are currently mapping onto the framework a range of existing courses relating to teaching, offered by the Scottish deaneries and other Scottish-based institutions. We are working towards developing a template for standardizing course descriptors to be used by all. The descriptors will aim to identify the level or depth at which each outcome is addressed in a course. Such standardized descriptors should assist doctors to make informed choices about their own professional development. Ultimately the aim is to produce a comprehensive portfolio of courses which support clinical teaching.

\section{Assessing personal learning needs}

Using the framework to describe the effective teacher allows medical teachers to identify their own personal needs across all areas, and to plan their own training and development programme. If course providers use the framework and further specify the extent to which the various learning outcomes are covered in their courses, doctors will be able to compare and choose courses relevant to their needs and interests at any one time.

The framework can therefore also provide a way forward for the development of a programme of training in teaching with the long-term aim of covering the needs of all career levels from pre-registration house officer to consultant.

\section{Identifying gaps in course provision}

The framework has been used by course providers throughout Scotland to identify which of the learning outcomes are covered by each of their courses. This, in turn, is helping to identify overlap and gaps in current provision in Scotland.

\section{Evaluating courses}

The framework can be used for evaluating courses and for designing assessment instruments (although we are still some way from formally assessing teaching).

\section{Staff planning}

The framework will also prove useful in planning for and appointing teaching staff. All competences outlined in the framework will be required within an organization, but will not necessarily be required or expected from one individual. The framework can assist in identifying the organization's requirements.

\section{Conclusion}

This framework provides an explicit and structured basis for assessing the educational needs of those doctors involved in teaching and training and providing a curriculum for their training. Course providers can use the framework to identify gaps and guide their curriculum planning. Doctors can use the framework to assess their training needs and make informed choices with regard to courses.

The strengths of the framework are:

- It provides a description of competences relevant to good teaching.

- It ensures that a holistic approach to teaching and training is adopted; one that will help doctors more easily recognize their educational responsibilities as well as recognize the other personal and professional attributes which contribute to being an effective medical educator.

- It enables the identification of overlap/duplication of courses provided throughout Scotland.

- It can be used to identify gaps in the current provision.

- It can be used to produce a standardized set of course descriptors which will allow doctors to make informed choices with regard to their CPD teaching activities.

- It can be used for evaluating courses on teaching and training.

- It can give guidance on staff planning, to ensure an organization has a balance of teaching expertise.

- It is applicable to both undergraduate and postgraduate teaching and training in the hospital and the community.

We recognize that the framework has its weaknesses, for example, some of the outcomes may be too broad to have real meaning and may require further refinement hence the desire to encourage further debate and discussion. 
In conclusion, what we have presented is a comprehensive framework for describing the effective teacher in the clinical setting. We believe that the framework and the outcomes would benefit from a wider audience at this stage. It is in this spirit that we put forward the framework so that an improved one could be published.

\section{Contributors}

$\mathrm{EAH}, \mathrm{MF}$ and $\mathrm{RMH}$ were responsible for the initial development of the model, and all authors for feedback and refinement of the model. Application of the model to existing courses was carried out by EAH, GB, EG, JML, LL-B, PM and RO. The manuscript was written by $\mathrm{EAH}$, and interim drafts were critically reviewed for intellectual content by EAH, GB, MF, EG, RMH, JML, LL-B and RO. All authors gave final approval to the manuscript.

\section{Funding}

This initiative was supported by the Scottish Council for Postgraduate Medical and Dental Education (SCPMDE).

\section{References}

1 Calman KC. Postgraduate Medical and Dental Education in Scotland. Edinburgh: Scottish Office; 1991.

2 SCOPME (Standing Committee on Postgraduate Medical and Dental Education). Teaching Hospital Doctors and Dentists to Teach: its Role in Creating a Better Learning Environment. Proposals for Consultation. London: SCOPME; 1992.

3 SCOPME. Teaching Hospital Doctors and Dentists to Teach: Creating a Better Learning Environment in Hospitals: 1. London: SCOPME; 1994.

4 SCOPME. Creating a Better Learning Environment in Hospitals: 2: Making the Most of Formal Educational Opportunities for Hospital Doctors and Dentists in Training. London: SCOPME; 1994.

5 British Medical Association. Report of the Working Party on Medical Education. London: BMA; 1995.

6 General Medical Council. The New Doctor. London: GMC; 1997.

7 General Medical Council. The Early Years. London: GMC; 1998.

8 General Medical Council. The Doctor as Teacher. London: GMC; 1999.

9 Whitehouse A. Warwickshire consultants' 'Training the trainers' course. Postgrad Med f 1997;73:35-8.

10 Hargreaves DH. Teacher development in hospital medicine and dentistry. Med Educ 1999;33:637-8.

11 Dearing R. Higher Education in the Learning Society: Report of the National Committee of Inquiry Into Higher Education. London: HMSO; 1997.
12 Garrick R. Higher Education in the Learning Society: Report of the Scottish Committee of the National Committee of Inquiry Into Higher Education. London: HMSO; 1997.

13 Challis M, Williams J, Batstone G. Supporting pre-registration house officers: the needs of educational supervisors of the first phase of postgraduate medical education. Med Educ 1998;32:177-80.

14 SCOPME. Teacher Development in Hospital Medicine and Dentistry. London: SCOPME; 1999.

15 Harden RM, Crosby J. AMEE education guide no 20: the good teacher is more than a lecturer - the twelve roles of the teacher. Med Teacher 2000;22 (4):334-47.

16 Spady WG. Organising for results: the basis of authentic restructuring and reform. Educational Leadership 1988;46(2): 4-8 (October).

17 AMEE. Outcome-Based Education. AMEE Education Guide No 14. Dundee: AMEE; 1999.

18 Allan J. Learning outcomes in higher education. Stud Higher Educ 1996;21 (1):93-106.

19 Ross N, Davies D. AMEE guide no 14: outcome-based education: Part 4 - outcome based learning and the electronic curriculum at Birmingham Medical School. Med Teacher 1999;21 (1):26-31.

20 Stritter FT, Bland CJ, Youngblood PL. Determining essential faculty competencies. Teaching Learning Med 1991;3 (4):232-8.

21 Irby DM. What clinical teachers in medicine need to know. Acad Med 1994;69 (5):333-41.

22 Litzelman DK, Stratos GA, Marriot DJ, Skeff KM. Factorial validation of a widely disseminated educational framework for evaluating clinical teachers. Acad Med 1998;73 (6):688-95.

23 Pinsky LE, Monson D, Irby DM. How excellent teachers are made: reflecting on success to improve teaching. Adv Health Services Educ 1998;3:207-15.

24 Sidford I. The learning needs and qualifications of GP tutors. Educ Gen Pract 1998;9:6-13.

25 Stephens C, Woodcock A. What are the needs of new GP teachers? Educ Gen Pract 1999;10:237-44.

26 Wall D, McAleer S. Teaching the consultant teachers: identifying the core content. Med Educ 2000;34 (2):131-8.

27 Beaty L. The professional development of teachers in higher education: structures, methods and responsibilities. Innovations Educ Training Int 1998;35 (2):99-107.

28 Gosling D. Recruiting good teachers. New Acad 1997;6(1):12-5.

29 Harden RM, Crosby JR, Davis MH. AMEE guide no 14: outcome-based education: Part 1 - An introduction to outcome-based education. Med Teacher 1999;21 (1):7-14.

30 Harden RM, Crosby JR, Davis MH, Friedman M. AMEE guide no 14: outcome-based education: Part 5 - From competency to meta competency: a model for the specification of learning outcomes. Med Teacher 1999;21 (6):546-52.

31 Squires G. Teaching as a Professional Discipline. London: Falmer Press; 1999.

Received 22 March 2000; editorial comments to authors 22 fune 2000; accepted for publication 15 August 2000 